〔80〕高分子皮膜の気体透過性

第 2 報 自動記録化による気体透過測定装㯰の試作と

それによる初期計算法について

(1958 年 11 月 19 日受理)

伊 滕 行 雄*

\begin{abstract}
要旨従来，気体透過量の測定はマノメーターによる圧力変化と時間の関保図から行なわれてきた。 そのために取扱の简単で精確な自動記録化が切望されて、二，三の試みがなされているが十分とはいいにくい。 筆者は差圧計と非接着型抵抗線ひずみ計を用いることによって自動記録化を行ない，取扱の容易さ，再現性の 優秀さ，透過機の解明などの利点を確認した。またその自動記録の圧力と時間の関係図から高分子皮膜の気

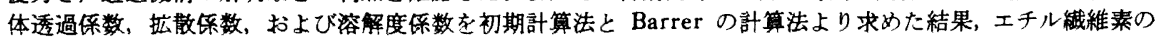
ような拉散俰数の大きいものを除いては大体において良い一致を示した。よって初期計算法を用いることに よって, 漣れ時間の大きい皮膜の気体透過の測定時間を約半分に短䄸でき，また從来 Barrer の計算方法によ って得ていた比故的信頼性の少ない，拡散倸数，溶解度係数をこの初期計算法で照合することによって，信頼 度を高めることができる。
\end{abstract}

\section{1. 锗言}

気体透過測定装置の自動記録化については, 二,三の試 みがなされているが、いずれも分とはいえない。たと えば B. Rosen") のサーミスターによる自動記録化は, 気体の種類による補正がなされなければならない。また ASTM D1434-56 T ${ }^{2}$ に採用されている水銀柱に白金線 を連結して，その抵抗変化を記録する方法は，水銀柱と 白金線の接触などの難点から高精度は望めない。よって 筆者は非接着型抵抗線ひずみ計と差圧計などを用いて気 体透過測定装置の自動記録化を試みた。またその自記さ れた压力と時間の曲線のらちから, 遅れ時間の大きい気 体一高分子皮膜について, W.A. Rogers ${ }^{3)}$ がガラスの $\mathrm{He}$ 透過について用いた初期計算法によって, 拡散係数, 溶 解度係数, および透過倸数を算出し, 従来から筆者らが 用いている R.M. Barrer の計算法の結果と対比して, そ の妥当性を検討した。

\section{2. 装置}

この装置は微少の圧力変化をひする計の抵抗変化に 変えることによって自動記録化したものである。これを 第 1 図に示した。試料皮膜を透過してきた気体はbへ導 びかれる。しかして a 部分は常に $1 \times 10^{-3} \mathrm{mmHg}$ 程度 の真空に保たれておるから，aとbの間にあるダイアフ ラム(ここでは防食を考えて 18-8 Cr-Ni 薄板を使用し た）は透過してきた気体の圧力によって，時間とともに 変形が增大する。この変形量はロッドによって非接着型 抵抗線ひずみ計へみちびかれる。ゲージブリッジの 1 組 がひっぱり応力,もしくは圧縮応力を受けると,他の 1 組

* 工業技萿院産業工芸試験所(東京都大田区下丸子 313)

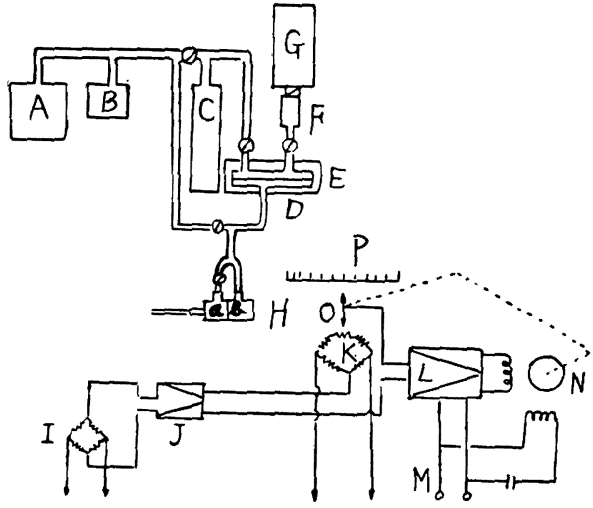

A. 真空ポンプ, B. 気圧調整槽, C. $1 \mathrm{~m}$ マ, メーター，D. 透過カップ，E．試料，F．ガス 洗浄器, G. ガス貯槽, H. 差圧計, I. アウト サイドプリッジ，J. 前圆堌幅器 (プレアンプ), K. インターールブリッジ, L. 增幅器, M. AC 100V， N. パランシングモーター，O．スラ イドワイヤー, P. スケール

第 1 図 装置の概略

は圧縮応力,もしくはひっぱり応力を受けるから、その結 果, その抵抗変化によって電位差が生ずる。その電位差 を前直增幅器によって增幅する。その電压に相当する量 だけバランシングモーターが動き, 鋼線が記録紙面を滑 走することによって圧力変化が記録される。記録紙の紙 送りは別のモーターで一定速度で行なう。紙送り速度は $0.1 \mathrm{~mm}$ のポリェチレン皮膜の温度 $25^{\circ} \mathrm{C}$, 酸素の場合に は $2.5 \mathrm{~mm} / \mathrm{min}$ 程度が最適であり，これを目安に試料皮 膜の透過量の大きさに応じて，歯車交換により紙送り速 
度を変える。また縦軸の圧力の目盛りも皮膜の透過量の 大きさに応じて, 増幅器の入力を変えることによってた だちに変えられる。透過量の大きい気体や, 皮膜の場合 には電位差を前置增幅器で増幅する必要はない。圧力変 化は前置增幅器を用いることによって $0.01 \mathrm{mmHg}$ まで は十分に把握できる。抵抗線ひずみ計のタイムレスポン スは非常に高いから, 透過の遅れ時間の測定にはほとん ど問題にならない。

もちろん，記録計の目盛指度はあらかじめチェックし ておかなければならないし、ひずみ計の部分は正確に垂 直に取り付けなければならない。またこの回路全体は使 用前に安定に達するためのある時間を必要とする。

\section{3. 実測}

第 2,3 図に㬰測の一例を示した。この結果遅れ時問が 正確に把握でき, それから拡散保数, 溶解度係数の計算 が容易である。さらに $d p / d t$ が一定に達する以前の圧力 変化の状態については, 従来の方法では明確に捕えら

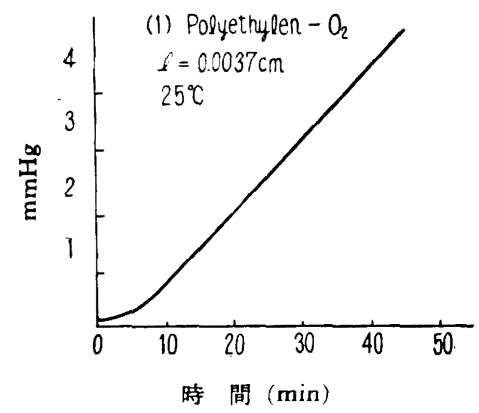

第 2 図透過量(圧力) と時間の関倸

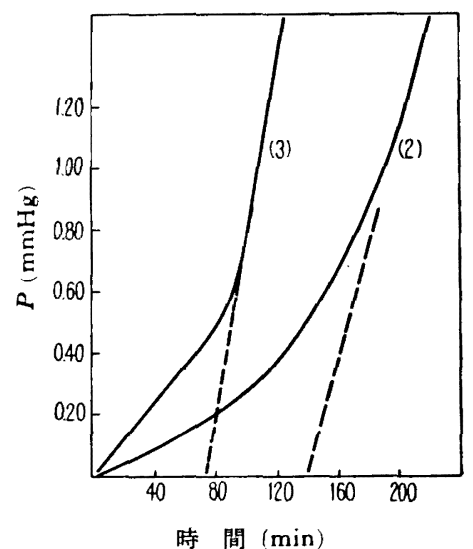

(2) polyethylen, $\mathrm{N}_{2}, l=0.099 \mathrm{~mm}, 19^{\circ} \mathrm{C}$

(3) Ethylcellulose, $\mathrm{N}_{2}, l=0.227 \mathrm{~mm}, 17^{\circ} \mathrm{C}$

第 3 図透湓量(任力の增加) と時間
れなかったが、この方法によれば皮膜, 気体, 測定条件 の相違によって定常状態に達する前の透過の状態には明 らかに異なることがわかる。定常状態に達した後の值に ついてはほとんど従来の方法と同じ結果が得られる。遅 れ時間が数分のものの測定は従来の方法よりは容易に 測定できるが，遅れ時間が短いために拡散係数の計算に 及ぼす誤差は不可避である。前置増幅器を用いれば 0.01 $\mathrm{mmHg}$ の圧力変化が記録されるから, 高分子皮膜の透 過量の測定には十分であり，さらに鋭敏さを望むときは b の容積を小さくすることによって目的が達せられる。 この方法は再現性, 取扱の単純さ, 個人誤差の少ないな どの利点を有する。

\section{4. 初期計算法の適用について}

前述のように, 遅れ時間の大きい高分子皮膜で窒素の 上5な難透過性気体の透過量を測定する場合や，炭酸ガ スのよ5に比較的透過しやすい気体であっても，ポリ塩 化ビニル，ナイロンなどの難透過皮膜を測定する場合に は，長時間を必要とする。この不便さは自動記録化によ って一応解決できるが，そのよ5な時間を一定温度に保 つこともなかなか大変である。しかし $d p / d t$ が一定に達 しない時間に扔いて, 拡散係数, 溶解度俰数, 透過係数 の初期計算ができればさらに便利である。これについて は Courant-Hilbert が Fick 法則の短い時間における 解をといている5)。また W.A. Rogers が石英ガラスの He 透過に用いて十分に使用できることを報告してい る ${ }^{3)}$ 。しかし拡散係数, 溶解度係数の大きい高分子皮膜 の気体透過にこれを用いることができるかどらか不明で ある。筆者は前述および従来の測定結果からこれを試み た。

今まで筆者が測定結果に使ってきた透過係数などの算 出方法を述べると次のと㧍りになる”。皮膜を通して拡 散する気体量 $(q)$ は

$$
q=V \mid A \cdot d p / d t
$$

定常状態においては $p \ll p_{1}$ であるから

$$
q=P p_{1} / l
$$

また皮膜の単位容橨あたりに保持される気体量は濃度 の時間变化に等しいと考えて

$$
-\Gamma q=d c / d t
$$

（2）は Fick の第 1 法則の特別な場合である。

$$
q=-D \nabla C
$$

(3), (4) から Fick の第 2 法則が遒かれる(拡散係数 $D$ が濃度 $C$ に依存しないと仮定して)。

$$
d c / d t=D \nabla^{2} C
$$

ついで境界面においてーンリーの法則がなりたつもの 
と考える。

$$
C_{1}=S \cdot p_{1}
$$

境界条件として

$$
\begin{array}{cl}
t \text { のすべての值において } & x=0 \text { において } C=C_{1} \\
& x=l \text { において }(2) \text { 条 } \\
& \text { 件から近似的に } C=0 \\
t=0 \text { において } l \leq x>0 \text { では } C=0
\end{array}
$$

(5)の解をフェリー級数を仮定したとき，(4)などに入 れると

$$
\frac{d p}{d t}=\left(\frac{A \cdot D \cdot S}{V \cdot l}\right) p_{1}\left\{1+\sum_{m=0}^{\infty} 2 \cos \pi m \exp \left(\frac{-m^{2} \pi^{2} D t}{l^{2}}\right)\right\}
$$

(7)は十分な時間において $d p / d t$ は一定に達する。

$$
\frac{d p}{d t}=\frac{A \cdot D \cdot S}{V} \cdot \frac{p_{1}}{l}
$$

(8)に(1)，(2) を代入すると

$$
P=D \cdot S
$$

よって

$$
P=\frac{V \cdot l}{A} \cdot \frac{1}{p_{1}} \cdot \frac{d p}{d t}
$$

さらに(7)を $t=0$ から $t=t$ まで皘分すると

$$
\begin{aligned}
p & =\frac{A \cdot D \cdot S}{V \cdot l} p_{1}\left\{t-\frac{l^{2}}{6 D}-\frac{2 l^{2}}{\pi^{2} D}\right. \\
& \left.\times \sum_{m=1}^{\infty}(-1)^{m} \frac{\exp \left(-m^{2} \pi^{2} D t / l^{2}\right)}{m^{2}}\right\}
\end{aligned}
$$

十分大きい時間では第 3 項は無視できるから

$$
\begin{gathered}
p=\left(\frac{A \cdot D \cdot S}{V \cdot l}\right) p_{1}(t-\theta) \\
\theta=\frac{l^{2}}{6 D}
\end{gathered}
$$

しかるに一方, Courannt-Hilbert ${ }^{3), 5)}$ らは (7) を変掺 して

$$
\frac{d p}{d t}=\frac{2 A}{V} S p_{1}\left(\frac{D}{\pi t}\right)^{\frac{1}{2}} \sum_{m=0}^{\infty} \exp \left\{-\left(\frac{l^{2}}{4 D t}\right)(2 m+1)^{2}\right\}
$$

$t$ が小さいときは指数の第 1 項以外は省略できる。しか して両辺に $t^{\frac{1}{2}}$ をかけて両辺の対数をとると

$$
\ln t^{\frac{1}{2}} \frac{d p}{d t}=\ln \left\{\left(\frac{2 A}{V}\right) S p_{1}\left(\frac{D}{\pi}\right)^{\frac{1}{2}}\right\}-\frac{l^{2}}{4 D t}
$$

(15)式を第 4 図のよ5に示すと，その勾配からDが求ま

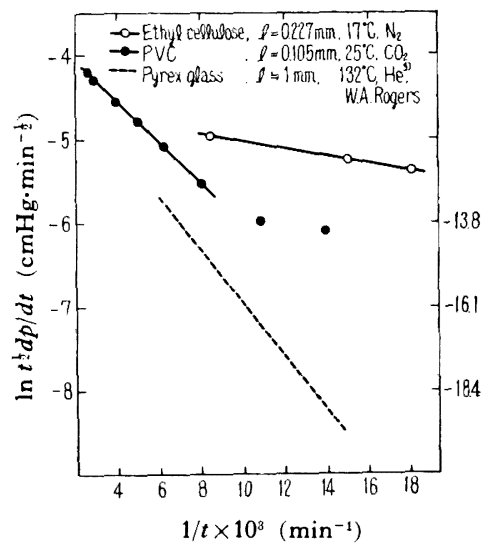

第 4 図初期計算法の適用例

$$
\text { 勾配 }=-\frac{l^{2}}{4 D}
$$

る。さらに溶解度係数 $S$ は次のように求まる。

$$
S=\left(\frac{\pi}{D}\right)^{\ddagger} \frac{V}{2 A} \frac{1}{p_{1}}\left(t^{\ddagger} \frac{d p}{d t}\right) \exp \left(\frac{l^{2}}{4 D t}\right)
$$

ただし以上の記号中, $C$ : 濃度, $t$ : 時間, $p, p_{1}$ : 低, 高 圧側の圧力, $A$ : 皮膜の面積, $l$ : 皮膜の厚さ, $V:$ 低圧 側の容積, $P$ : 透過係数，なお本報の $A$ は第 1 報 ${ }^{6)}$ と同 様であり, $V$ についてはその外に $50.61,25.85 \mathrm{cc}^{3}$ などを 使用して測定した值である。

Barrer の解法 (late method, 以下 Bとする) の (11) 式は $t$ が大きいときになりたつのに比して, Courannt の解法 (early method, 以下Cとする)の (14) 以下は $t$ が小さいときになりたつ。第 3 図の測定結果などを(15) 式に例をとって第 4 図に示した。この図からある時間範 囲内においてはほぼ直線性が満足される。第 1 表に各種 高分子皮膜の同一の测定結果から, $D, S, P$ を示した。 $P$, $S$ の単位は，それぞれ皮膜の両面の圧力差に比例すると 考えて $\mathrm{cmHg}$ 単位になおし，気体の容積を標準温度に 換算して示した。

まず拡散係数についてみるとエチル 繊維素について は，はなはだ相違するが，他の皮膜についてはかなり良 い一致を示す。これは第 3 図の時間と圧力の関係図から 説明できる。すなわちポリェチレンなどの皮膜について は(11)式のような傾向を示すが，エチル㵶維素では，透 過の初期状態の $t$ と $p$ の関係は(11) 式に合致しない。こ れはェチル㵶維素皮膜の場合に(7)式の条件を満足しな い拡散が行なわれるのか，あるいは皮膜の厚さの影響か はっきりしないが7) 纎維素誘導体皮膜全体が, 多少とも エチル繊維素と同様な傾向を示す点から考えて，これら の皮膜の透過，拡散を考える場合に無条件に(13)式ある いは(16)式を適用することに疑問を威ずる。緎維素誘導 
第 1 表 late method (B) と early method(C) による拡散係数などの比較

\begin{tabular}{|c|c|c|c|c|c|c|c|c|c|}
\hline \multirow{2}{*}{ 皮膜の種 類 } & \multirow{2}{*}{$\left(\begin{array}{ll}\text { 厚 } & さ \\
\left(\mathrm{mrn} \cdot 10^{2}\right.\end{array}\right)$} & \multirow{2}{*}{ 気 体 } & \multirow{2}{*}{ 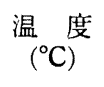 } & \multicolumn{2}{|c|}{$D\left(\mathrm{~cm}^{2} / \mathrm{sec} \cdot 10^{9}\right)$} & \multicolumn{2}{|c|}{$S\left(\mathrm{cc} / \mathrm{cm}^{8} \mathrm{cmHg} \cdot 10^{2}\right)$} & \multicolumn{2}{|c|}{$P\left(\begin{array}{c}\mathrm{cc} \cdot \mathrm{cm} / \mathrm{cm}^{2} \cdot \mathrm{sec} \cdot \\
\mathrm{cmHg} \cdot 10^{11}\end{array}\right)$} \\
\hline & & & & B & C & B & $\mathrm{C}$ & B & $\mathrm{C}$ \\
\hline $\begin{array}{l}\text { ポリエチレン } \\
\text { (Tenite) }\end{array}$ & 7.8 & $\mathrm{~N}_{2}$ & 19 & 1.44 & 1.44 & 6.2 & 3.9 & 8.9 & 5.6 \\
\hline (Alathon) & 5.5 & " & 18 & 0.50 & 0.55 & 11.2 & 4.4 & 5.6 & 2.4 \\
\hline & & " & 10 & 0.31 & 0.31 & 14.5 & 9.2 & 4.5 & 2.9 \\
\hline$($ Hizex $)$ & 5.8 & $"$ & 18 & 0.34 & 0.23 & 10.4 & 8.2 & 3.5 & 1.9 \\
\hline " $"$ & 5.8 & $" \prime$ & 25 & 0.52 & 0.75 & 8.8 & 3.9 & 4.6 & 2.9 \\
\hline エチル繊維素 & 22.7 & $\prime \prime$ & 17 & 19.2 & 78.0 & 2.2 & 0.03 & 43.0 & 2.3 \\
\hline 酢酸酪酸繊維素 & 6.6 & " & 17 & 0.86 & 0.73 & 7.9 & 8.7 & 6.8 & 6.3 \\
\hline 二酢酸繊維素 & 12.0 & " & 52 & 2.10 & 2.07 & 3.0 & 1.4 & 6.3 & 3.0 \\
\hline $\begin{array}{l}\text { 硝酸繊維素 } \\
\text { (Tcp 50\%) }\end{array}$ & 25.7 & " & 32 & 4.55 & 4.9 & 2.2 & 1.4 & 10.0 & 7.0 \\
\hline $\begin{array}{l}\text { ポリ塩化ビ二ル } \\
\text { (Dop 33\%) }\end{array}$ & 10.5 & $" \prime$ & 14 & 2.0 & 1.5 & 3.9 & 5.0 & 7.8 & 7.6 \\
\hline ポリェチレンテレフタレート & 2.6 & $\mathrm{CO}_{2}$ & 24 & 0.16 & 0.15 & 10.3 & $10.9_{5}$ & $1.7_{0}$ & $1.6_{4}$ \\
\hline ポリビニルフォルマール & 5.4 & " & 27 & 0.44 & 0.41 & $9.7_{0}$ & $9.0_{3}$ & $4.3_{0}$ & $3.7_{0}$ \\
\hline ポリ塩化ビニル & 10.5 & $" \prime$ & 25 & 1.66 & 1.75 & $2.4_{8}$ & $2.1_{2}$ & $4.1_{2}$ & $3.7_{1}$ \\
\hline ネオプレン & 104.0 & $\mathrm{O}_{2}$ & 25 & 304 & 300 & $0.07_{8}$ & $0.06_{8}$ & 22.0 & 20.4 \\
\hline
\end{tabular}

体にあっても可塑剤を添加した皮膜はきれいな曲線を示 す。他の高分子皮膜についてはかなり良い一致を示す が, Rogers の石英ガラスの He 透過実験に比して $\ln t$ $d p / d t$ と $1 / t$ の間の直線性の範囲は約半分であるという ことも，高分子皮膜の気体透過が Fick 法則に全面的に 従らか, どらか疑問を示すものである7。 。た測定方法， 測定条件について前述の境界条件を满足させるよう十分 注意を払う必要がある。その一例として，次のような実 験事実が認められた。第 5 図はポリ塩化ビニル皮膜の

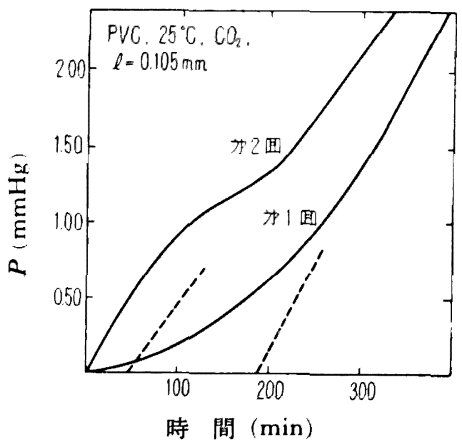

第 5 図透過量(圧力の増加)と時間
$\mathrm{CO}_{2}$ 透過の実例を示した。第 1 回の測定が終った後 20 分間皮膜の両面を真空にした後 $\mathrm{CO}_{2}$ を遒入して第 2 回 の測定を行なった。 $\theta$ は非常に異なる結果が得られた。 これは皮膜に残存している $\mathrm{CO}_{2}$ の濃度依存性によって 拡散，透過が大きくなったものと考えられる。次に 2 回 目の測定を行なった後 10 時間皮膜の両面を真空に保持 しておいてから，第 3 回目の測定を行なった。このよう に皮膜に $\mathrm{CO}_{2}$ が残存しない場合には, 1 回目の测定結果 とよく合致し，第 2 表に示したようにBとCによる計算 結果もよくあ5。4 回目には皮膜の両面を窒素中に 10 時間放置した後, 真空にしてから $\mathrm{CO}_{2}$ を導入して測定 した結果は 3 回目の測定値とほぼ等しい値が得られた。 よっていずれにしても遅れ時間の 2 倍以上の時間は皮膜 の両面を真空にするか, 测定気体よりも溶解度保数の小 さい気体中に保った後, 測定を行なえばよい再現性が得 られることがわかった。

さらに溶解度係数を対比してみると，拡散係数が比較 的に良い一致を示したのに, 溶解度係数の $S_{B}$ と $S_{C}$ と はよい一致を示す場合と，あまりよい一致を示さない場 合があるが，おおむね $S_{B}>S_{C}$ である。(17)式は(14) 式で指数の第 1 項以外を省略した結果を用いているか ら， $S_{C}$ はどうしても小さく出るわけであり，拡散係数 
第 2 表 測定值のバラツキ, ポリ塩化ビニル, $25^{\circ} \mathrm{C}, \mathrm{CO}_{2}, l=0.105 \mathrm{~mm}$

\begin{tabular}{|c|c|c|c|c|c|c|c|c|}
\hline \multirow{2}{*}{ 回 } & \multirow{2}{*}{ 数 } & \multirow{2}{*}{$\begin{array}{c}\begin{array}{c}\text { 遅れ時間 } \\
(\mathrm{min})\end{array} \\
\end{array}$} & \multicolumn{2}{|c|}{$D \cdot \mathrm{cm}^{2} / \mathrm{sec} \cdot 10^{9}$} & \multicolumn{2}{|c|}{$S \cdot \mathrm{cc} / \mathrm{cm}^{3} \cdot \mathrm{cmHg} \cdot 10^{2}$} & \multicolumn{2}{|c|}{$P \cdot \mathrm{cc} \cdot \mathrm{cm} / \mathrm{cm}^{2} \cdot \mathrm{sec} \cdot \mathrm{cmHg} \cdot 10^{11}$} \\
\hline & & & $\mathrm{B}$ & $\mathrm{C}$ & $\mathrm{B}$ & $\mathrm{C}$ & $\mathrm{B}$ & $\mathrm{C}$ \\
\hline & 1 & 186 & 1.66 & 1.75 & 2.48 & 2.12 & 4.12 & 3.71 \\
\hline & 2 & 46 & 6.70 & 8.0 & 0.64 & 0.21 & 4.30 & 1.68 \\
\hline & 3 & 182 & 1.69 & 1.84 & 2.49 & 2.09 & 4.22 & 3.84 \\
\hline
\end{tabular}

の大きい高分子皮膜ではそのきき方も大きく $S_{B}$ と $S_{C}$ の値の相違も大きくなるはずである。実験結果をみると 拡散係数の小さい皮膜が比較的良い一致を示している。 ポリ塩化ビニルなど前報で述べたように $S_{B}$ については 正しい溶解度係数と考えられない反面， $S_{C}$ については 少なくとも上記のような点を考虑しなくてはならない。 また溶解度倸数の值は標準偏差が $50 \%$ 采 にも達するよ らなバラッキの大きいものであるから，測定回数を多く するとともに, 両解法によって得られた值があまり異な る場合には再考すべきであると考えられる。

透過係数について見ると㹡散係数, 溶解度係数の関俰 からおおむね $P_{C}$ は $P_{B}$ に比して小さい。 $P_{B}$ は定常 状態で測定が行なわれて得られた結果であり，再現性も 良いから $P_{B}$ については信頼性が大きいものと考えられ る。ただ $D_{C}$ と $S_{C}$ の積が $P_{C}$ と考えること自体には問 題があると思われる。

\section{5. 結語}

1. 非接着型抵抗線ひずみ計を用いて, 自動記録化に よる透過装置を試作しその有用性を確めた。

2. 上記の装置を用いて記録した圧力一時間曲線から Currant の解法に従って高分子皮膜の透過係数，㧪散係 数および溶解度俰数を求め, 従来の Barrer の解法によ る結果と対比して次の結論を得た。 a)エチル繊維素などの特殊なものを除いて拡散係数 は良い一致を示す。

b) 溶解度係数は全体として小さめに出るが，注意深 く測定を行なえばかなり一致した結果も得られる。

よって初期計算法で高分子皮膜の透過性を計算するこ とによって，測定時間を短縮することができ，また両計 算法を併用することによって拡散係数, 溶解度係数の值 の信頼性を高めることができる。

付 韵：本研究にあたりご指導をいただいた東京工大教 授井上幸彦，当所福网部長に対して深即申し上げる。なお本研 究の一部は高分子学会年会 (昭和 33 年 6 月)に㧍いて発表した。

\section{文献}

1) B. Rosen and J.H. Singleton: J. Polym. Sci., 22, 173(1956)

2) ASTM D1434-56T: ASTM Standards (1956); Supplement-Part 6, 55

3) W.A. Rogers et al: J. Appl. Phys., 25, 868(1954)

4) R.M. Barrer: Trans. Faraday Soc., 35, 628(1939)

5) Currant-Hilbert: Methoden der Mathmatishen Physik, 63 (Julius Springer, Berlin, 1931)

6) 伊藤行雄：高化，投稿中

7）l，Vなどの項が非常に大きく影響することが，そ の後の研究の結果判明した。

\title{
Permeability of Highpolymer-Films
}

\section{Automatic Recording, Gas-Polymer Film Permeameter by Straingage, and on the Approximation by Early Method}

By Yukio Ito*

\begin{abstract}
Hitherto, gas transmission rates of high polymer films were measured by employing a periodic collection of increase of pressure with time. So, permeameter whose simplicity of operation and exactly measurement is to be desired earnestly. Here noted automatic recording permeameter by unbonded strain gage has many points of excellence, such as reproducibility, extreme convenience, a minimum of personal errors, the simplicity of operations and useful analysis of diffusion behavior. Diffusion constant $(D)$, solubility constant $(S)$ and permeability constant $(P)$ of high polymer films were calculated by the early method using the automatic recording chart. $D, S$ and $P$ determined by the late method coincided with the values by the early method except ethylcellulose. For this reason I think the early method is useful not only to reduce measuring time but to check the value by the late method.
\end{abstract}

* Industrial Arts Institute of Japanese Government (313, Shimomaruko Ōta-ku, Tokyo) 